ACTA MYCOLOGICA

Vol. 45 (2): 163-167

2010
Dedicated to Professor Barbara Gumińska on the occasion of her eighty-fifth birthday

\title{
New records of Microbotryum species parasitizing Caryophyllaceae from Ukraine
}

\author{
KYRYLO G. SAVCHENKO ${ }^{1,2}$ and VASYL P. HELUTA ${ }^{2}$ \\ ${ }^{1}$ Institute of Evolution and Faculty of Natural Sciences, University of Haifa, \\ Mt. Carmel, 31-905 Haifa, Israel, savchenko.kyryll@gmail.com \\ ${ }^{2}$ M.G. Kholodny Institute of Botany of the National Academy of Sciences of Ukraine \\ ${ }^{2}$ Tereschenkivska St., UA-01601 Kyiv, vheluta@botany.kiev.ua
}

Savchenko K. G., Heluta V. P: New records of Microbotryum species parasitizing Caryophyllaceae from Ukraine. Acta Mycol. 45 (2): 163-167, 2010.

Four records of smut fungi belonging to the genus Microbotryum Lév. are reported. Two species were found on new hosts, namely M. dianthorum on Dianthus borbasii and $D$. pseudoserotinus and M. superbum on D. stenocalyx. Microbotryum lagerheimii on Lychnis viscaria is a new species for Ukraine.

Key words: smut fungi, Microbotryum, Dianthus, Lychnis

\section{INTRODUCTION}

The comprehensive information regarding European smut fungi has been given in the monograph by Vánky (1994), where the author listed 400 species known for the continent and 70 provisory species. However, some new species have been described later and species known in other regions have been found here. Thus, in the new check-list of smut fungi (Vánky 2005a) 14 additional species were included. Currently, there are 38 species which were described or collected after 1994 in Europe (Almaraz, Telleria 1998; Bauer et al. 2008; Denchev 2007; Denchev, Giraud and Hood 2009; Lutz et al. 2005, 2008; Lutz, Vánky 2009; Piątek 2006; Prillinger et al. 2009; Vánky 1998, 2003, 2005a,b, 2007, 2008a,b, 2009; Vánky and Berner 2003; Vánky, Horita and Jage 2005a; Vánky, Jage and Scholz 2005b; Vánky et al. 2008; Vánky, Lutz 2007; Vánky, Scholz 2001). Among them there are also representatives of the genus Microbotryum Lév., mainly described as new species, e.g., M. adenopetalae M. Lutz, Kemler et Chleb., M. cartusianorum Denchev, Giraud et M.E. Hood, M. chloranthae-verrucosum M. Lutz, Göker, Piątek, Kemler, Begerow et Oberw., M. lagerheimii Denchev, M. minuartiae M. Lutz, Piątek, Kemler et Chleb., M. saponariae M. Lutz, Göker, Piątek, Kemler, 
Begerow et Oberw., M. schykoffianum Giraud, Denchev et M.E. Hood, M. silenesacaulis M. Lutz, Piątek, Kemler et Chleb., M. silenes-dioicae Giraud, Denchev et M.E. Hood, and M. silybum Vánky et Berner (Denchev 2007; Denchev et al. 2009; Lutz et al. 2005, 2008; Vánky, Berner 2003). Microbotryum jehudanum (Zundel) Vánky was found for the first time in the territory of Europe (Vánky et al. 2005b). Another species well known as Ustilago superba Liro was transferred into the genus Microbotryum with creation of a new combination M. superbum (Liro) Denchev, Giraud et M.E. Hood (Denchev et al. 2009).

It is known that many species of the genus Microbotryum develop in the anthers of plants belonging to the Caryophyllaceae. They are the so-called "anthericolous smut fungi". These species easily produce hybrid forms which can subsequently become new species (Chlebicki, Suková 2005). Therefore, for each region the establishment of the host-plants ranges of these species thorough morphological and, when it is possible, molecular investigations are all important.

Ukraine is a region with a considerable diversity of vascular plants, including the Caryophyllaceae with the level of endemism at about $24 \%$ (Fedoronchuk 2009). So, during the studies on smut fungi both rare species belonging to the genus Microbotryum and new species of their host-plants may be found. This paper deals with such fungi which we have found on the Lychnis L. and Dianthus L. species in 2009.

\section{MATERIALS AND METHODS}

Sori and spores were studied using dried herbarium specimens. For light microscopy (LM), spores were dispersed in a droplet of lactophenol on a microscope slide, covered with a cover glass, gently heated to boiling point to rehydrate the spores and eliminate air bubbles, and examined at $400 \times$ and $1000 \times$ magnification. For scanning electron microscopy (SEM), spores were placed on double-sided adhesive tape, mounted on a specimen stub, sputter-coated with gold, ca. $20 \mathrm{~nm}$, and examined in SEM at $30 \mathrm{kV}$. The studied materials are stored in the National Herbarium of Ukraine of M.G. Kholodny Institute of Botany (KW).

\section{RESULTS AND DISCUSSION}

SMUt FUNGi On Dianthus SPECIES. For a long time, the smut fungi which develop their sori in the anthers of different Dianthus species were included in Ustilago violacea Pers.: Pers., a combined cosmopolitan parasite of hosts belonging to the Caryophyllaceae. However, in 1924 Liro described two separate species, U. dianthorum Liro in the anthers of $D$. deltoides L. and $U$. superba Liro on D. superbus L. Much later, a new genus Microbotryum was offered for some anthericolous smut fungi, and $U$. violacea s. lat. was included in this genus as M. violaceum (Pers.) G. Deml et Oberw. (Deml, Oberwinkler 1982). Scholz and Scholz (1988) transferred smut fungi that 


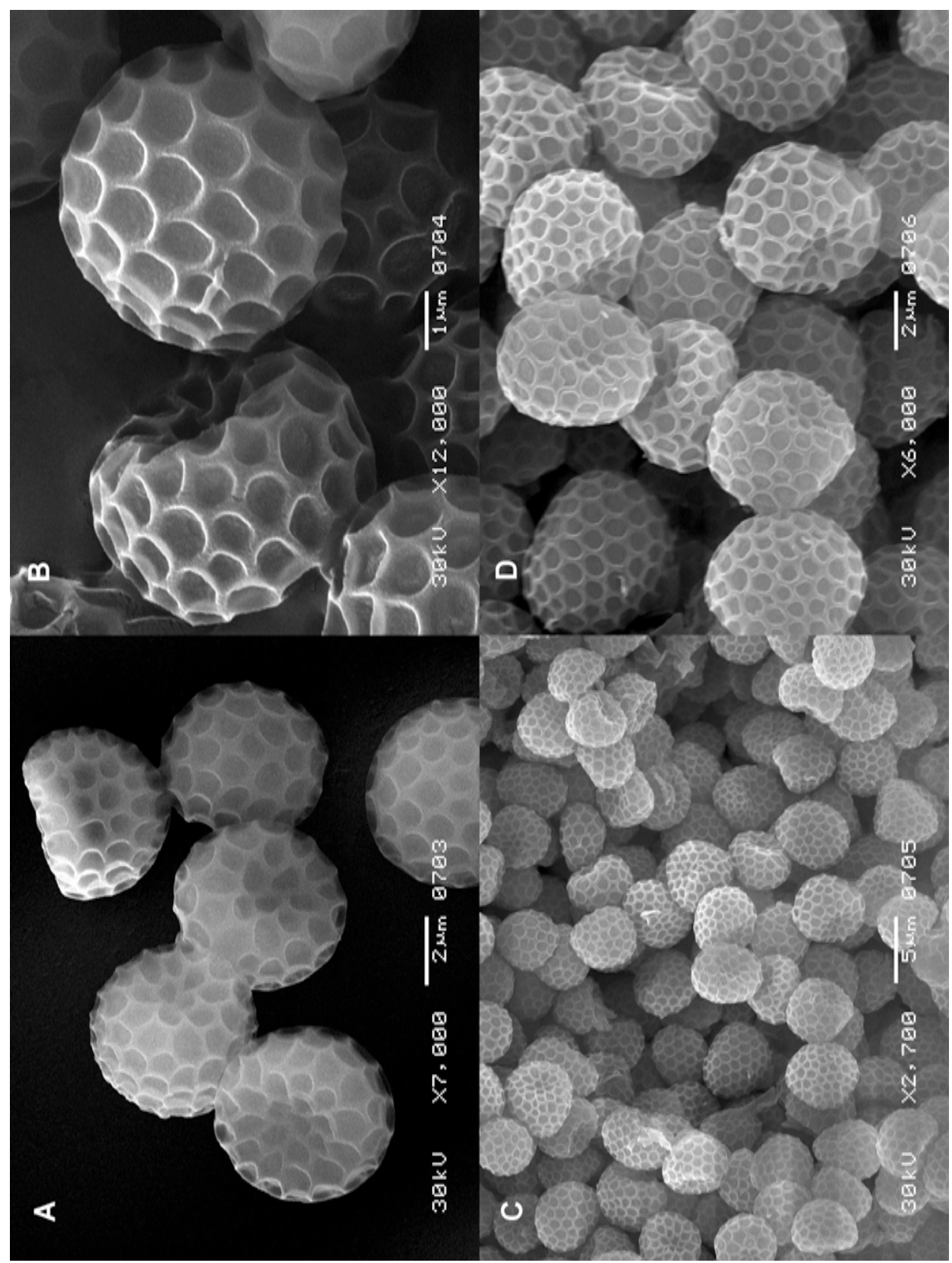

Fig. 1. Spores of Microbotryum dianthorum: A, B - on Dianthus borbasii; C, D - on Dianthus pseudoserotinus. All photos in SEM. Scale bars for A, D $=2 \mu \mathrm{m} ; \mathrm{B}=1 \mu \mathrm{m} ; \mathrm{C}=5 \mu \mathrm{m}$. 


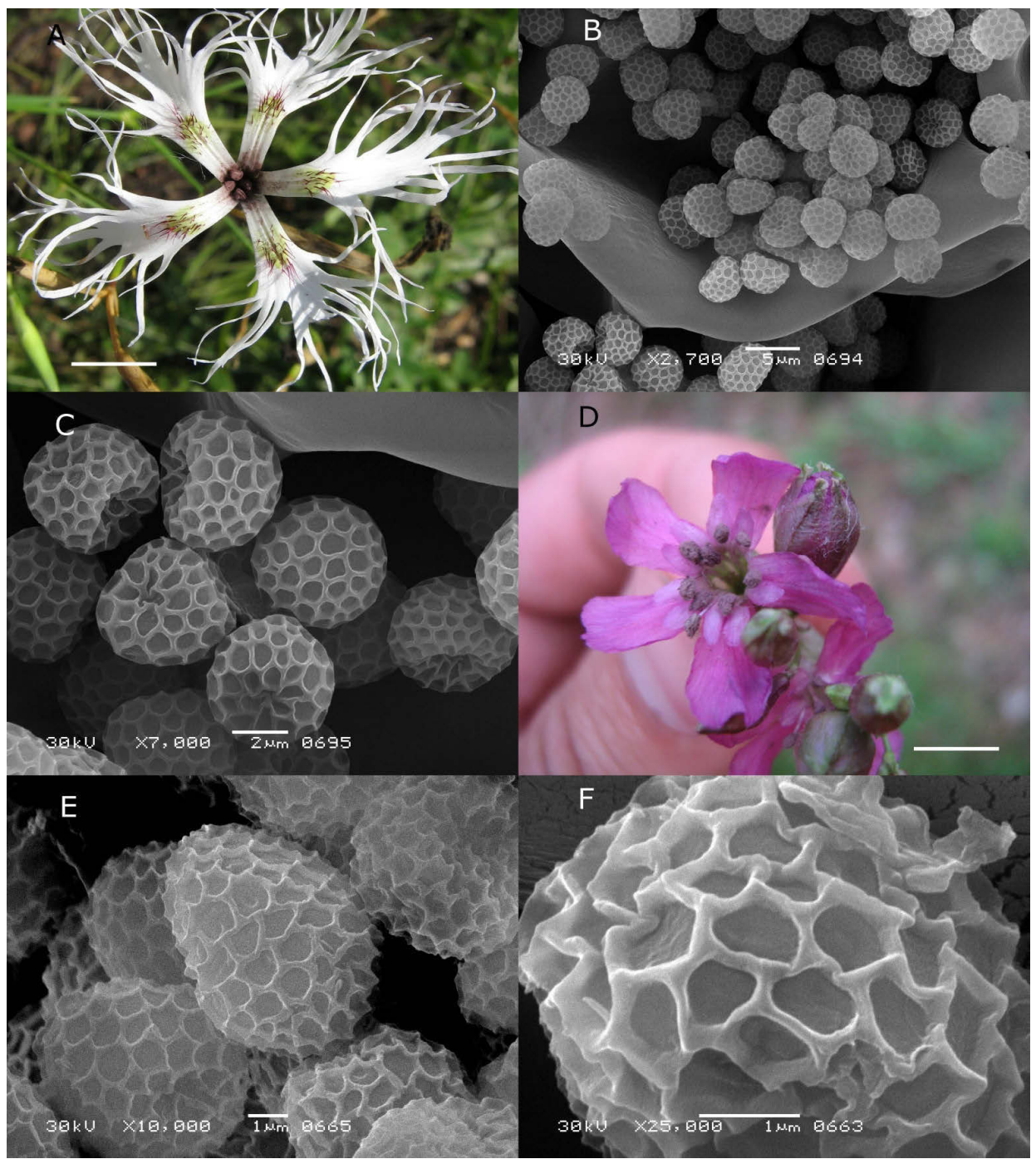

Fig. 2. Microbotryum superbum on Dianthus stenocalyx: A - infected flower, B, C - spores. Microbotryum lagerhemii Denchev on Lychnis viscaria: D - infected flowers, E, F - spores; B, C, E, F - in SEM. Scale bars for A, D = $5 \mathrm{~mm}$; B $=5 \mu \mathrm{m} ; \mathrm{C}=2 \mu \mathrm{m} ; \mathrm{E}, \mathrm{F}=1 \mu \mathrm{m}$. 
developed in anthers of many Dianthus species into M. dianthorum (Liro) H. Scholz et I. Scholz, but Liro's U. superba was left in M. violaceum. Denchev and Scharkova (1997), having investigated 229 specimens of smut fungi on 22 Dianthus species, concluded that all of them belong to the same species, namely $M$. violaceum $\mathrm{s}$. lat. However, Vánky (2004) supposed that this species can be divided into smaller ones through the use of analyses of as many of type specimens as possible with employment of both traditional morphological and molecular-phylogenetic methods. Such studies have been made by Lutz et al. (2005, 2008), and their results confirmed the separation of $M$. dianthorum. However, within this species a great variability in the spore dimensions was found. In addition, the number of meshes per spore diameter also strongly varied. In spite of this, all specimens were clustered together by molecular data. Similar investigations regarding other fungi from $M$. violcaeum-complex parasitizing $D$. sylvestris Wulfen and D. cartusianorum L. showed insignificant morphological differences between both of these samples and from other specimens of this complex. However, they differed by molecular-biological data and features of microsatellite analyses. Thus, they were cryptic species (Denchev et al. 2009). The results of molecular-phylogenetic investigations also made it possible to restore a species status of smut fungus on $D$. superbus and regard it not any more as $U$. superba but as M. superbum (Denchev et al. 2009).

Only two species of smut fungi parasitizing Dianthus species were known in Ukraine, e.g., $M$. dianthorum (reported as $U$. dianthorum) on $D$. pseudoarmeria M. Bieb. from the forest-steppe zone and M. superbum (reported as U. superba) on D. superbus from Polissia region (Zerova et al. 1971). No specimens of these fungi were found in the National Herbarium of Ukraine of the M.G. Kholodny Institute of Botany (Fungi of Ukraine 1996). So far, the smut fungi on Dianthus have been considered to be rare in Ukraine. However, in summer 2009 we collected three specimens of the anthericolous smut fungi on $D$. borbasii Vandas, D. pseudoserotinus Błocki (D. arenarius p.p.) and D. stenocalyx Juz. (D. superbus p.p.). The first and the second of them were identified by us as M. dianthorum and the last as M. superbum. The characteristics of these fungi on new hosts are given below.

Microbotryum dianthorum (Liro) H. Scholz et I. Scholz

Fig. 1

Sori develop in the anthers of host plants. Spore mass powdery, from medium violet to brownish violet. Spores globose or subglobose, sometimes ovoid to slightly elongated, 5-8 $\times$ 5-7 $\mu \mathrm{m}$. Spore wall reticulate, on Dianthus borbasii 5-7 meshes per spore diameter, meshes irregularly polygonal to rounded, 0.6-0.9 $\times 0.8-1 \mu \mathrm{m}$; on D. pseudoserotinus (6) 7-9 meshes per spore diameter, meshes rounded to slightly irregularly polygonal, $0.6 \times 0.7 \mu \mathrm{m}$.

Distribution in Ukraine. On Dianthus borbasii Vandas: Cherkasy region, Kaniv distr., Trakhtemyriv Regional Landscape Park, 4959'10' N, 31 22'20” E, 03.06.2009, leg. K. Savchenko (KW 36849F). On D. pseudoarmeria M. Bieb.: RightBank Forest-Steppe zone (Zerova et al. 1971). On D. pseudoserotinus Błocki: Volhynian region, Lubeshiv distr., Pripyat-Stokhid National Park, 51 '53'16" N, $24^{\circ}$ 57'26" E, 09.08.2009, leg. K. Savchenko and V. Heluta (KW 36851F).

Microbotryum superbum (Liro) Denchev, Giraud et M.E. Hood Figs 2 A-C

Sori develop in the anthers of host plants. Spore mass dark violet brown, powdery. Spores subglobose, ovoid to slightly elongated, sometimes rather irregular, 
5-6 (6.5) $\times 4-6 \mu \mathrm{m}($ at the mean $5.6 \times 4.7 \mu \mathrm{m})$. Spore wall reticulate, $5-7$ meshes per spore diameter, meshes slightly irregular polygonal, $0.7 \times 0.8 \mu \mathrm{m}$.

Distribution in Ukraine. On Dianthus stenocalyx Juz.: Volhynian region, Lubeshiv distr., Pripyat-Stokhid National Park, mixed forest, 51 53'40" N, $24^{\circ}$ 57'35" E, 08.08.2009, leg. V. Heluta (KW 36852F). On D. superbus L. s. lat.: Right-Bank and Left-Bank Polissia (Zerova et al. 1971). Microbotryum superbum differs from M. dianthorum in having smaller spores and by the color of spore mass.

Anthericolous SMUt fungus on LyCHNis. During field research in Cherkasy region (Ukraine) intense development of smut fungus in the anthers of Lychnis viscaria L. was recorded. Thus, about $20 \%$ of plants in the studied population were affected. The fungus was identified as Microbotryum lagerheimii. This species has been recently described (Denchev 2007) in the anthers of L. alpina L. and L. viscaria. It is closely related to M. silenes-inflatae (DC. ex Liro) G. Deml et Oberw. known on Lychnis alpina, Silene vulgaris subsp. glareosa (Jord.) Marsden-Jones et Turrill, S. vulgaris subsp. vulgaris (Moench) Garcke (Oberna behen (L.) Ikonn.), S. cucubalus Wibel, S. inflata Sm. and S. venosa Asch.) but differs in having far less (small or medium) intensity of spore mass coloration (Denchev, Minter 2008). Microbotryum lagerhemii is also known from Czech, Finland, Germany, Italy, Latvia, Norway, Poland, Russia, and Sweden (Denchev 2007). Thus, the fungus is a European endemic within a boreal-temperate area. In Ukraine it was found for the first time.

Microbotryum lagerheimii Denchev

Figs 2 D-F

Sori develop in the anthers of host plant. Spore mass pale to medium violet, powdery. Spores globose, subglobose or slightly ellipsoidal to irregular, 4.5-8 $\times$ 4.5-7 $\mu \mathrm{m}$, length/width ratio $1.06-1.18$, practically hyaline to weakly coloured. Spore wall reticulate, 5-8 meshes per spore diameter, meshes globose to ellipsoidal and irregularly elongated, 0.3-1.1 $\mu \mathrm{m}$.

Distribution In Ukraine. Cherkasy region, Kaniv distr., Trakhtemyriv Regional Landscape Park, 4959’06” N, 31 ²0’53” E, 04.06.2009, leg. K. Savchenko (KW 36366F).

Acknowledgments. The authors would like to express their deep thanks to Dr. Mykola Fedoronchuk (Kyiv, Ukraine) for checking of Dianthus species, to Mr. Jason Somers for checking our English, and to Mr. Viktor Novychenko for assistance with the SEM photographs.

\section{REFERENCES}

Almaraz T., Telleria T.M. 1998. On Ustilago sparti (Ustilaginales, Basidiomycotina). Mycotaxon 67: 495504.

Bauer R., Lutz M., Begerow D., Piątek M., Vánky K., Bacigálova K., Oberwinkler F. 2008. Anther smut fungi on monocots. Mycol. Res. 112: 1297-1306.

Chlebicki A., Suková M. 2005. Two Microbotryum species from Himalayas. Mycotaxon 93: 149-154.

Deml G., Oberwinkler F. 1982. Studies in Heterobasidiomycetes. Part 24. On Ustilago violacea (Pers.) Rouss. from Saponaria officinalis L. Phytopath. Zeitschr. 104: 345-365.

Denchev C.M. 2007. Microbotryum lagerheimii sp. nov. (Microbotryaceae). Mycol. Balcan. 4: 61-67.

Denchev C.M., Minter D.W. 2008. Microbotryum silenes-inflatae. IMI Descriptions of fungi and bacteria. No. 1763: 1-4.

Denchev C.M., Giraud T., Hood M.E. 2009. Three new species of anthericolous smut fungi on Caryophyllaceae. Mycol. Balcan. 6: 79-84.

Denchev C., Sharkova S. 1997. Taxonomic revision of Microbotryum (Ustilaginales) on Dianthus. Phytol. Balcan. 3 (1): 105-112. 
Fedoronchuk M.M. 2009. Analiz endemizmu Caryophyllaceae Juss. flory Ukrainy. Ukr. Bot. Zhurn. 66 (4): 541-549.

Fungi of Ukraine. 1996. A Preliminary Checklist. Egham, UK, International Mycological Institute \& Kiev, Ukraine, M.G. Kholodny Institute of Botany.

Liro J.I. 1924. Die Ustilagineen Finnlands I. Ann. Acad. Sci. Fenn., Ser. A. 17 (1): 1-636.

Lutz M., Göker M., Piątek M., Kemler M., Begerow D., Oberwinkler F. 2005. Anther smuts of Caryophyllaceae: molecular characters indicate host-dependent species delimitation. Mycol. Progress. 4 (3): 225-238.

Lutz M., Piątek M., Kemler M., Chlebicki A., Oberwinkler F. 2008. Anther smuts of Caryophyllaceae: Molecular analyses reveal further new species. Mycol. Res. 112: 1280-1296.

Lutz M., Vánky K. 2009. An annotated checklist of smut fungi (Basidiomycota: Ustilaginomycotina and Microbotryales) in Slovenia. Lidia 7 (2/3): 33-78.

Piątek M. 2006. Entyloma crepidis-tectori and Urocystis deschampsiae, two new smut fungi from Europe. Pol. Bot. J. 51 (2): 165-172.

Prillinger H., Wuczkowski M., Lopandic K., Bauer R., Molnár O., Sterflinger K. 2009. Schizonella caricisatratae (Ustilaginomycetes): a new cryptic species on Carex atrata from Austria. Mycol. Progress 8: $157-164$.

Scholz H., Scholz I. 1988. Die Brandpilze Deutschlands (Ustilaginales). Englera 8: 1-691.

Vánky K. 1994. European smut fungi. Gustav Fischer Verlag, Stuttgart, Jena, New York.

Vánky K. 1998. Taxonomical studies on Ustilaginales. XVIII. Mycotaxon 69: 93-115.

Vánky K. 2003. Taxonomical studies on Ustilaginales. XXIII. Mycotaxon 85: 1-65.

Vánky K. 2004. Anther smuts of Caryophyllaceae. Taxonomy, nomenclature, problems in species delimitation. Mycol. Balcan. 1: 189-191.

Vánky K. 2005a. European smut fungi (Ustilaginomycetes p.p. and Microbotryales) according to recent nomenclutare. Mycol. Balcan. 2: 169-177.

Vánky K. 2005b. Taxonomical studies on Ustilaginomycetes - 25. Mycotaxon 91: 217-272.

Vánky K. 2007. Taxonomical studies on Ustilaginomycetes - 27. Mycotaxon 99: 1-70.

Vánky K. 2008a. Taxonomical studies on Ustilaginomycetes - 28. Mycotaxon 106: 133-178.

Vánky K. 2008b. Two new Thecaphora species, T. ulicis and T. hosakiae (Ustilaginomycetes) on Fabaceae. Mycol. Balcan. 5: 129-133.

Vánky K. 2009. Taxonomic studies on Ustilaginomycetes - 29. Mycotaxon 110: 289-324.

Vánky K., Berner D. 2003. Microbotryum silybum sp. nov. (Microbotryales). Mycotaxon 85: 307-311.

Vánky K., Horita H., Jage H. 2005a. Entyloma cosmi sp. nov. on Cosmos bipinnatus (Compositae). Mycoscience 46: 364-366.

Vánky K., Jahe H., Scholz H. 2005b. Three smut fungi (Ustilaginomycetes) new for Europe. Nova Hedwigia 80: 45-53.

Vánky K., Lutz M. 2007. Revision of some Thecaphora species (Ustilaginomycotina) on Caryophyllaceae. Mycol. Res. 111: 1207-1219.

Vánky K., Jage H., Schlüter U., Sluschny H. 2008. Stegocintractia capitata sp. nov. (Ustilaginomycetes) from Germany. Mycol. Balcan. 5: 79-81.

Vánky K., Scholz H. 2001. Three new species of smut fungi (Ustilaginomycetes). Nova Hedwigia 72: 391-398.

Zerova M.Ya, Morochkovskyi S.F., Radziyevskyi G.G., Smitska M.F. 1971.Vyznachnyk grybiv Ukrainy. Tom IV. Basydiomitsety: Dakrymitsetalni, Tremelalni, Auricularialni, Sazhkovydni, Irzhasti. Kyiv, Naukova dumka. 